\title{
Haemobartonellosis in a Domestic Cat in Indonesia: a Case Study
}

\author{
Ivan Satriawan $^{1}$, Devi Intan Dyah Ayu Octaviani ${ }^{2 *}$ \\ ${ }^{1}$ Veterinary Practicioner Doctor at Gloria Vet, Bandung. \\ ${ }^{2}$ Student of Veterinary Medicine Faculty, University of Brawijaya, Malang \\ *Email : deviintan@student.ub.ac.id
}

\begin{abstract}
Haemobartonellosis is a disease caused by Haemobartonella felis or Mycoplasma haemofelis, which attacks red blood cells. Ctenocephalides felis could transmit Haemobartonellosis. Further, vertical transmission from mother to offspring and blood transfusion from infected animals could transfer the disease to other animals. This report aimed to describe the diagnosis and medical treatment of haemobartonellosis in a domestic cat in Indonesia. Physical examinations and blood analysis were carried out. The cat weighed $1,4 \mathrm{~kg}$ with $39,3^{\circ} \mathrm{C}$ temperature, CRT was three seconds, mucosa looked pale, and many Ctenocephalides felis fleas were found. The clinical symptoms detected were weakness, loss of appetite, and hair loss. A blood test indicated normocytic normochromic anemia. The rod-like formation within erythrocytes in blood smear was observed. Infection with Hemobartonella felis was diagnosed based on the blood test and the presence of numerous Ctenocephalides felis. Doxycycline was administrated at $10 \mathrm{mg} / \mathrm{kg} \mathrm{BW}$ once a day for 21 days. The cat recovered clinically after 21 days, with a good appetite, normal mucosal color, and normal temperature.
\end{abstract}

Keywords : blood, cat, haemobartonella felis

\begin{abstract}
ABSTRAK
Haemobartonellosis adalah penyakit yang disebabkan oleh Haemobartonella felis atau Mycoplasma haemofelis, yang menyerang sel darah merah. Ctenocephalides felis dapat menularkan haemobartonellosis. Penularan dapat terjadi secara vertikal yaitu dari induk ke anak dan dari darah hewan yang terinfeksi. Studi ini bertujuan untuk mendeskripsikan diagnosis dan pengobatan hemobartonellosis pada kucing domestik di Indonesia. Diagnosa dilakukan berdasarkan pemeriksaan fisik dan darah. Hasil studi menunjukkan bahwa kucing yang diperiksa memiliki berat badan $1,4 \mathrm{~kg}$ dan suhu $39,3^{\circ} \mathrm{C}$, CRT tiga detik, mukosa tampak pucat, dan banyak ditemukan kutu Ctenocephalides felis. Gejala klinis yang terdeteksi adalah kondisi lemah, kehilangan nafsu makan, dan bulut rontok. Tes darah menunjukkan bahwa kucing dalam kondisi anemia normokromik normositik. Selain itu, pengamatan terhadap rod-like formation pada eritrosit juga diamati. Infeksi Hemobartonella felis didiagnosis berdasarkan tes darah dan hasil menunjukkan bahwa terdapat banyak Ctenocephalides felis. Terapi yang diberikan adalah pemberian doksisiklin dengan dosis $10 \mathrm{mg} / \mathrm{kgBB}$ sekali sehari selama 21 hari. Hasil menunjukkan bahwa secara klinis kucing telah sembuh setelah 21 hari, dengan nafsu makan yang baik, warna mukosa normal, dan suhu normal.
\end{abstract}

Kata Kunci : darah, haemobartonella felis, kucing

\section{INTRODUCTION}

Haemobartonellosis is a disease caused by Mycoplasma haemofelis, also known as Hemobartonella felis. In cats, the transmission of Hemobartonella felis could occur transplacentally from mother to fetus, horizontally from one cat to another through the scratch, or the transmission from arthropod vectors such as fleas and mosquitoes (Soto et al., 2017). Despite high incidence, scientific 
reports on haemobartonellosis in cats in Indonesia are not common. This study aimed to describe a case of presumptive haemobartonellosis in a cat in Bandung, Indonesia.

\section{CASE REPORT}

\section{History}

The animal was a female mixed breed cat, five months old, weighing $1,4 \mathrm{~kg}$, with black-brown hair color. On Monday, $20^{\text {th }}$ of January 2020, the cat was presented to Gloriavet Bandung for decreased appetite, hair loss, and weakness. The cat previously had vomiting and diarrhea on $5^{\text {th }}$ of January 2020 but stopped after a few days.

\section{Hematological and Blood Smear Examinations}

The blood tests were carried out, including hematology and blood smear. The result is shown in Table 1 . The hematological examination indicated that the cats suffered anemia, indicated by a reduction of hemoglobin level, hematocrit, and erythrocyte. In addition, reticulocytosis and monocytosis were observed.

The examination of the blood smear showed the presence of inclusion body presumptive $H$. felis bacteria at the marginal body of erythrocytes (Figure 1). The differential diagnoses of the inclusion body could be AIHA (Autoimmune Hemolytic Anemia), Babesiosis, Cytauxzoonosis, and Haemobartonellosis.

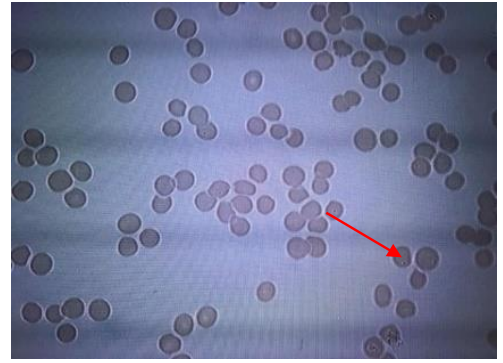

Figure 1. The blood smear appearance of presumptive Haemobartonellosis in a cat. The inclusion body is attached to the erythrocyte membrane (red arrow).

Table 1. Haemotology test result of a cat suspected the Haemobartonellosis

\begin{tabular}{cccc}
\hline Parameter & Unit & Result & Normal range \\
\hline RBC & $\mathrm{M} / \mu \mathrm{L}$ & 5,82 & $6,54-12,20$ \\
$\mathrm{HCT}$ & $\%$ & 28,2 & $30,3-52,3$ \\
$\mathrm{HGB}$ & $\mathrm{g} / \mathrm{dL}$ & 8,3 & $9,8-16,2$ \\
$\mathrm{MCV}$ & $\mathrm{fL}$ & 48,5 & $35,9-53,1$ \\
$\mathrm{MCH}$ & $\mathrm{Pg}$ & 14,3 & $11,8-17,3$ \\
$\mathrm{MCHC}$ & $\mathrm{g} / \mathrm{dL}$ & 29,4 & $28,1-35,8$ \\
$\mathrm{RDW}$ & $\%$ & 22,5 & $15,0-27,0$ \\
$\% \mathrm{RETIC}$ & $\%$ & 1,1 & \\
RETIC & $\mathrm{K} / \mu \mathrm{L}$ & 61,7 & $3,0-50,0$ \\
RETIC-HGB & $\mathrm{Pg}$ & 21,7 & $13,2-20,8$ \\
$\mathrm{WBC}$ & $\mathrm{K} / \mu \mathrm{L}$ & 10,72 & $2,87-17,02$ \\
$\% \mathrm{NEU}$ & $\%$ & 62,7 & \\
$\% \mathrm{LYM}$ & $\%$ & 27,7 & \\
$\% \mathrm{MONO}$ & $\%$ & 8,9 & \\
$\% \mathrm{EOS}$ & $\%$ & 0,3 & \\
$\% \mathrm{BASO}$ & $\%$ & 0,4 & \\
$\mathrm{NEU}$ & $\mathrm{K} / \mu \mathrm{L}$ & 6,73 & $2,30-10,29$ \\
$\mathrm{LYM}$ & $\mathrm{K} / \mu \mathrm{L}$ & 2,97 & $0,92-6,88$ \\
$\mathrm{MONO} \uparrow$ & $\mathrm{K} / \mu \mathrm{L}$ & 0,95 & $0,05-0,67$ \\
EOS $\downarrow$ & $\mathrm{K} / \mu \mathrm{L}$ & 0,03 & $0,17-1,57$ \\
$\mathrm{BASO}$ & $\mathrm{K} / \mu \mathrm{L}$ & 0,04 & $0,01-0,26$ \\
$\mathrm{PLT}$ & $\mathrm{K} / \mu \mathrm{L}$ & 11 & $151-600$ \\
MPV & $\mathrm{fL}$ & 23,0 & $11,4-21,6$ \\
$\mathrm{PCT}$ & $\%$ & 0,03 & $0,17-0,86$ \\
& & &
\end{tabular}

\section{Diagnosis}

Based on clinical symptoms, physical and blood examination, the cat's diagnosis was suspect Haemobartonellosis. 


\section{Prognosis}

The prognosis of the case was Fausta. The prediction for haemobartonellosis was generally reported as dubious to Fausta. As many as $75 \%$ of cats survived from Haemobarthonellosis following proper treatments (Fathi et al., 2010).

\section{Treatment}

Doxycycline was given orally once a day for two weeks at $10 \mathrm{mg} / \mathrm{kg} \mathrm{BW}$. After two weeks of initial treatment, the cat was sent to the clinic for a check-up. The animal was in a better condition with a good appetite and looked more active. However, fleas remained abundant on the skin. Thus, further treatment given was broadly containing Fipronil(s)methoprene and Praziquantel at a dose recommended by the manufacturer.

\section{DISCUSSION}

The marked clinical sign of the cat indicated dehydration. Therefore initial action provided was fluid therapy for rehydration. Blood examination was performed after the rehydration, included hematology and blood smear to confirm the diagnosis.

The leukocyte component associated with parasitic infections is eosinophils which indicate the number of parasites. (Mahasri et al., 2011) explained that the parasite infestation could trigger eosinophils elevation. The cat showed eosinopenia but a monocytosis. Monocytosis might be triggered by bacteremia (Mahasri et al., 2011).

The cat has low hematocrit, erythrocyte, and hemoglobin levels, which indicate anemia. The blood test also indicated normocytic normochromic anemia, increasing in the number of reticulocytes. Mycoplasma felis and a few blood parasites infect erythrocytes and cause hemolytic anemia in cats. This anemia will trigger the production of immature erythrocytes called reticulocytes of bone marrow and force reticulocytes to move into the bloodstream to replace reduced circulating erythrocytes.

On a blood smear test, the parasite could appear as a rod shape, round, ring, or pleomorphic at the marginal part of the red blood cells. The morphology of $H$. felis cannot be differentiated from other parasites such as Babesia sp. and Cytauxzoon sp. by microscopic examination with low magnification, but the presence of numerous fleas in the cat could indicate that the blood parasite was Haemobarthonella sp.

Feline haemobartonellosis is a disease caused by Haemobartonella felis or Mycoplasma haemofelis, which causes acute and chronic hemolytic anemia, depending on the degree of infection and the causative agent activity (Weiss and Wardrop, 2010). Mycoplasma haemofelis is a rickettsia. This microorganism has tiny, rod, round or ring-shaped, found singly or in the cell wall chains and Gram-negative. Rickettsia attach to the surface of red blood cells. This microorganism is usually less than 1000 $\mathrm{nm}$ in diameter and has no cell wall. The Mycoplasma haemofelis adhere to the red blood cell membranes,causing indentation and depression on the cell surface so that 
the erythrocyte becomes brittle during the infection (Tsachev, 2009).

Haemobartonellosis can be treated with antibiotics. Beta-lactam antibiotics such as Penicillins and Cephalosporins are ineffective for Haemobartonellosis treatment because Mycoplasma haemofelis lacks the cell wall. However, Tetracyclines (primarily Doxycycline) and Fluoroquinolones (for example, Marbofloxacin, Pradofloxacin) are adequate to $M$. haemofelis. Doxycycline is a broad-spectrum antibiotic that can prevent protein synthesis by binding to ribosomes in bacterial and parasite cells.

Preventing Haemobartonellosis from spreading among cat population can be performed by maintaining the cleanliness of individual cats and administering regular flea control.

\section{CONCLUSION}

The animal was diagnosed with suspected haemobartonellosis based on the clinical sign, the presence of numerous flea on the skin, and the presence of inclusion body on the marginal part of red blood cells. The success of the treatment using Doxycyline further support the diagnosis of Haemobarthonellosis.

\section{ACKNOWLEDGEMENT}

The authors acknowledge the owners of Gloria Vet Bandung for permission to use the data from their clinic for this publication. The authors also thank the Faculty of Veterinary Medicine,
Universitas Brawijaya, for facilitating a veterinary internship at Gloria Vet Bandung.

\section{REFERENCES}

Fathi, E., Sharifi, H., Mahdi, N. S. 2010. Haemobartonella felis in Tehran: follow-up, diagnosis, prevalence, clinical importance, laboratory evaluation, prognosis, and treatment of 23 infected cats (2003-2007). Comp Clin Pathol. 19(4):339-343.

Mahasri, G., Widyastuti, P., Sulmartiwi, L. 2011. Gambaran Leukosit Darah Ikan Koi (Cyprinus carpio) yang Terinfestasi Ichthyophthirius multifiliis pada Derajat Infestasi yang Berbeda dengan Metode Kohabitasi. JIPK. 3(1):91-96.

Soto, F., Walker, R., Sepulveda, M., Bittencourt, P., Acosta-Jamett, G., Müller, A. 2017. Occurrence of canine hemotropic mycoplasmas in domestic dogs from urban and rural areas of the Valdivia Province, southern Chile. Comparative Immunology, Microbiology and Infectious Diseases. 50:70-77.

Tsachev, I. 2009. Canine Granulocytic Anaplasmosis. Trakia Journal of Sciences. 7(1):68-72.

Weiss, D. J. and Wardrop, K. J. 2010. Schalm's Veterinary Hematology. State Avenue: Blackwell Pub. 